レーザー解説

\author{
ヘテロエピタキシャル成長技術を用いた \\ $\mathrm{Si}$ 基板上半導体レーザー
}

長谷川義晃*·江川孝志**・神保孝志**・梅野正義 ${ }^{*}, * *$

(1995年5月9日 受理)

\title{
Semiconductor Laser on Si Substrate Using Heteroepitaxial Growth Technique
}

\author{
Yoshiaki HASEGAWA *, Takashi EGAWA **, Takashi JIMBO** \\ and Masayoshi UMENO*, **
}

(Received May 9, 1995)

\begin{abstract}
Light emitting devices grown by heteroepitaxial growth technique such as $\mathrm{GaN} / \mathrm{Al}_{2} \mathrm{O}_{3}$, $\mathrm{ZnSe} / \mathrm{GaAs}$ and $\mathrm{GaAs} / \mathrm{Si}$ have a serious problem of reliability because of their high dislocation density. For example, GaAs-based light emitting diode (LED) and laser grown on Si substrates suffer from rapid degradation because of a high dislocation density $\left(>10^{6} \mathrm{~cm}^{-2}\right)$ and a large residual thermal stress $\left(\sim 10^{9} \mathrm{dyn} / \mathrm{cm}^{2}\right)$, which are introduced by the $\sim 4 \%$ lattice mismatch and the $\sim 250 \%$ difference in the thermal expansion coefficients between GaAs and Si. If the sizes of active regions in these devices are drastically reduced, the reliability can be remarkably improved due to low dislocation numbers. From this point of view, we demonstrated $\mathrm{AlGaAs} / \mathrm{GaAs}$ vertical cavity surface emitting laser (VCSEL), quantum wire-like laser and LED with self-assembled GaAs dots active region on Si. This novel technique is very promising for the improvement of reliability of light emitting devices with high dislocation density grown by heteroepitaxy.
\end{abstract}

Key Words: Heteroepitaxy, High dislocation density, Vertical cavity surface emitting laser, Quantum wire-like laser, Self-assembled GaAs dots

1.はじめに

高密度光ディスク用光源として活発に研究さ れている青色発光デバイスの構成材料である $\mathrm{ZnSe}$ な゙のII-VI族化合物半導体及びGaNなど
の窒化物系III-V族化合物半導体は格子整合す る基板がないため, $\mathrm{GaAs} \mathrm{Al}_{2} \mathrm{O}_{3}$ などの基板 が使用されている ${ }^{1-4)}$ 。このため，基板との界 面付近に転位が多数発生し, 活性層に貫通転位 が存在するようになる。活性層中の転位は発光

*名古屋工業大学電気情報工学科( T466 名古屋市昭和区御器所町)

**名古屋工業大学極微構造デバイス研究センター(テ466 名古屋市昭和区御器所町)

*Department of Electrical and Computer Engineering, Nagoya Institute of Technology (Gokiso-cho, Showa-ku, Nagoya 466)

* * Research Center for Micro-Structure Devices, Nagoya Institute of Technology (Gokiso-cho, Showa-ku, Nagoya 466) 
デバイスの信頼性に多大な影響を及ほすすこが 考えられるため, 実用化に向けては転位の低減 が急務である ${ }^{2,4)}$ 。また, 将来の光電子集積回 路や光インターコネクションを実現するキーデ バイスとして注目されている $\mathrm{Si}$ 基板上 $\mathrm{GaAs}$ 系 半導体レーザーでは，約4\%の格子不整合及び 約 2.5 倍の熱膨張係数差を有しながらも室温連 続発振しているが, $10^{6} \mathrm{~cm}^{-2}$ 以上の高密度転位 及び約 $10^{9} \mathrm{dyn} / \mathrm{cm}^{2}$ の高残留応力のために実用 に耐えうる長寿命レーザーはまだ実現されてい ない ${ }^{5-8)}$ 。このように, 近年の有機金属気相成 長(MOCVD; metal organic chemical vapor deposition) 法や分子線成長 (MBE; molecular beam epitaxy)法などの結晶成長技術の発達に より，物性定数差を超越したへテロエピタキ シャル成長の重要性が高まっているが, 結晶性 の改善が大きな課題となっている。 $\mathrm{Si}$ 基板上 $\mathrm{GaAs}$ 結晶 $(\mathrm{GaAs} / \mathrm{Si})$ の高品質化には, 選択成長

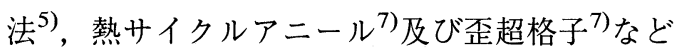
が用いられてきたが， $10^{6} \mathrm{~cm}^{-2}$ 台の転位密度が 大きな壁となっており何らかの新たなブレイク スルーが待たれる。最近, ヘテロエピタキシャ ル成長で発生する貫通転位を抑制するために異 種半導体基板同士を貼り合わせる直接接着技術 も研究され，InPを接着層としたSi基板上 $\mathrm{GaAs}$ 系半導体レーザーが作製されている ${ }^{9)}$ 。しかし ながら，プロセス時に生じる熱歪や接着界面で の高抵抗によりレーザーが急速劣化し寿命改善 には至っていない。一方, 活性層体積を低減し 内部に含まれる転位数を減少させることによ り，信頼性が改善される可能性がある ${ }^{10)}$ 。さ らに，実際の光電子集積回路の場合，既に極微 細化及び高集積化が発達している電子デバイス に適合する光インターコネクションを実現する ためには，現在よりも大幅に微小化及び低消費 電力化された発光デバイスが必要となるが，こ れは活性層体積を低減した構造を導入すること で可能になる。

本解説では， $\mathrm{Si}$ 基板上 $\mathrm{GaAs}$ 系発光デバイス の活性層体積低減を目指した, 垂直共振器型面 発光レーザー，擬量子細線レーザー及び自己形
成GaAs ドット状活性層を有する発光ダイオー ド(LED; light emitting diode)の試作について 報告し，その諸特性についても言及する。

\section{Si基板上面発光レーザー}

\section{1 結晶成長}

結晶成長は, 高周波加熱方式, 横型反応炉の 常圧MOCVD装置により行なった。III族原料 にはトリメチルガリウム(TMG), トリメチル アルミニウム(TMA)を，V族原料にはアルシン $\left(\mathrm{AsH}_{3}\right)$ を用い, ドーパントとしてn型にはセレ ン化水素 $\left(\mathrm{H}_{2} \mathrm{Se}\right), \mathrm{p}$ 型にはジエチル亜鉛(DEZ) を使用した。また，キャリアガスは水素である。 基板には[011]方向に $2^{\circ}$ off した(100)面のn型( $\mathrm{Sb}$ ドープ, $0.02 \Omega \cdot \mathrm{cm}) \mathrm{Si}$ 用いた。

\section{$2.2 \mathrm{Si}$ 基板上 $\mathrm{AlGaAs} / \mathrm{GaAs}$ 面発光レーザーの 作製}

微小化及び高集積化に優れ三次元光電子集積 回路用として期待される $\mathrm{Si}$ 基板上 $\mathrm{AlGaAs} /$ $\mathrm{GaAs}$ 面発光レーザーは，二段階成長法を用 いて, $\mathrm{n}^{+}-\mathrm{Si}$ 基板上に $400{ }^{\circ} \mathrm{C} て ゙$ 低温 $\mathrm{GaAs}$ 層 $(10 \mathrm{~nm})$ を成長し, 続いて $750{ }^{\circ} \mathrm{C} て ゙ \mathrm{n}^{+}-\mathrm{GaAs}$ バッ ファー層 $(0.8 \mu \mathrm{m})$ を成長後, 20 ペアの $\mathrm{n}$-AlAs $(71 \mathrm{~nm}) / \mathrm{n}-\mathrm{GaAs}(59 \mathrm{~nm})$ 分布反射型 (DBR; distributed Bragg reflector)多層膜反射鏡, n$\mathrm{Al}_{0.7} \mathrm{Ga}_{0.3} \mathrm{As}$ クラッド層 $(0.46 \mu \mathrm{m}), \mathrm{GaAs}$ 量子 井戸活性層 $(9 \mathrm{~nm})$ を $\mathrm{Al}_{0.3} \mathrm{Ga}_{0.7} \mathrm{As}$ 層 (上下各 $70 \mathrm{~nm})$ で挟んだ分離閉じ込めへテロ構造 ( $\mathrm{SCH}$; separate confinement heterostructure), $\mathrm{p}-\mathrm{Al}_{0.7} \mathrm{Ga}_{0.3} \mathrm{As}$ クラッド層 $(0.34 \mu \mathrm{m}), \mathrm{p}^{+}$- $\mathrm{GaAs}$ コンタクト層 $(80 \mathrm{~nm})$ を成長して作製した ${ }^{11,12)}$ 。 その断面走査電子顕微鏡(SEM; scanning electron microscope)写真をFig. 1に示す。ただし，基板の 界面から発生した転位が活性層へ伝搬するのを抑 制し結晶性を向上させるために, $\mathrm{n}^{+}-\mathrm{GaAs}$ 層成長 中に $\mathrm{AsH}_{3}$ 雲囲気中で $350{ }^{\circ} \mathrm{C}-850{ }^{\circ} \mathrm{C}$ の熱サイクル アニールを5回導入した7)。また, 光出射側の反射 鏡は電極を兼ねた $40 \mu \mathrm{m}$ 角の $\operatorname{AuZn}(50$ $\mathrm{nm}) / \mathrm{Au}(150 \mathrm{~nm})$ 金属反射鏡とした。このため, 注入電流がすべて金属電極直下に流れるもの 


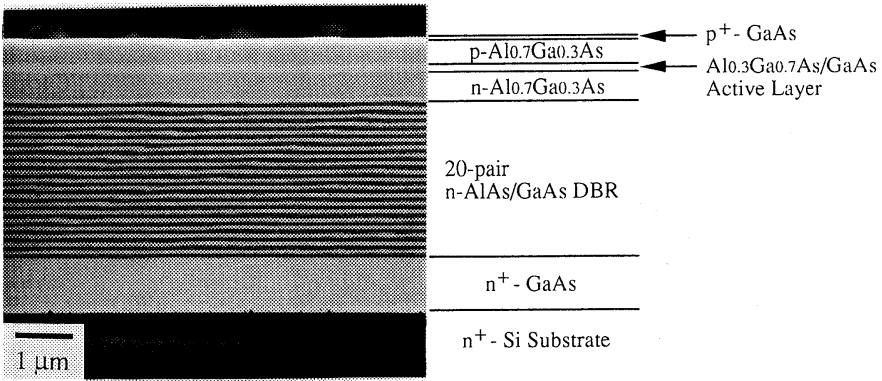

Fig. 1 Cross-sectional SEM micrograph of an AlGaAs/GaAs VCSEL on Si.

と仮定すると,この面発光レーザーの転位数は, $10 \mu \mathrm{m}$ 幅の電極空を有する共振器長 $300 \mu \mathrm{m}$ の従 来の $\mathrm{Si}$ 基板上 $\mathrm{AlGaAs} / \mathrm{GaAs}$ 端面発光量子井戸 レーザー ${ }^{8)}$ の転位数の約 $1 / 2$ に低減できることに なる。

$2.3 \mathrm{Si}$ 基板上 $\mathrm{AlGaAs} / \mathrm{GaAs}$ 面発光レーザーの 諸特性

AlAs/GaAs DBRは, Fig. 2に示すように, $820 \mathrm{~nm}-870 \mathrm{~nm}$ の波長帯域で $90 \%$ 以上の反射率 を有しており，波長 $860 \mathrm{~nm}$ で最高反射率は93 \%である。この值は理論反射率よりも6\%程度 低い值となっている。Fig. 3 に AlAs/GaAs DBRの断面透過電子顕微鏡 (TEM; transmission electron microscope) 写真を示す。図中,

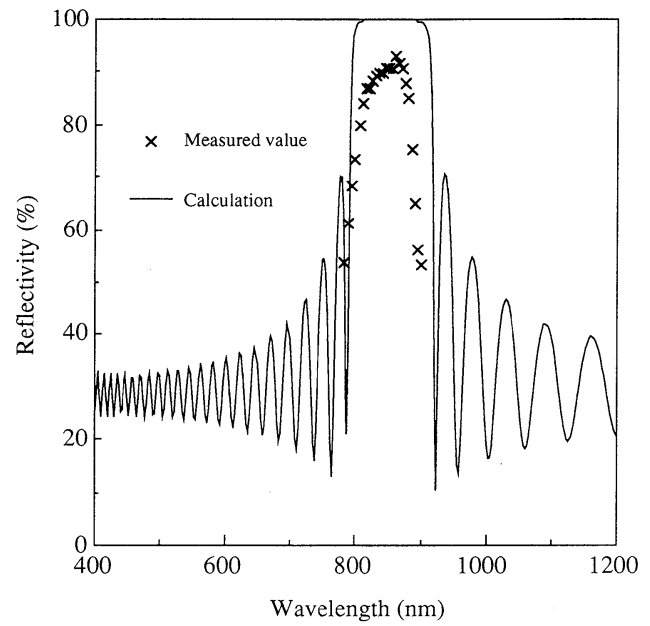

Fig. 2 Calculated and measured reflectivities of a 20-pair AlAs/GaAs DBR on Si.

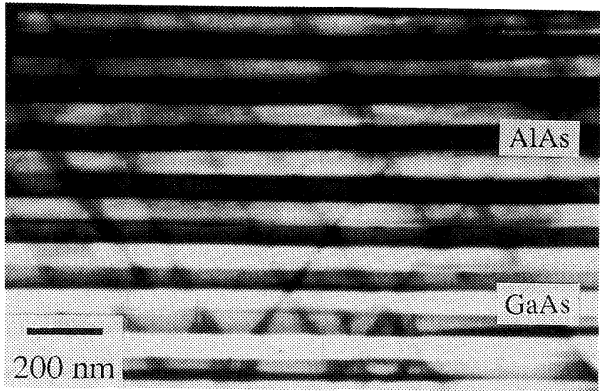

Fig. 3 Cross-sectional TEM micrograph of an AlAs/GaAs DBR on Si.

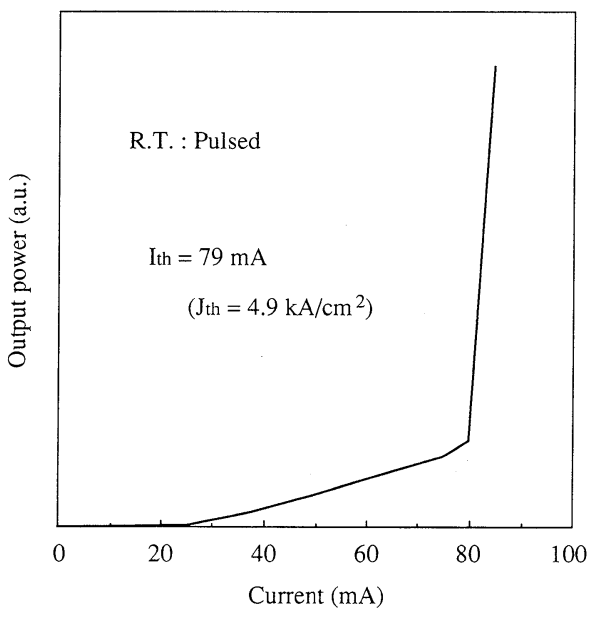

Fig. 4 Light versus current characteristic of a VCSEL on $\mathrm{Si}$ under pulsed condition at room temperature.

暗部はAlAs層，明部はGaAs層である。AlAs 及びGaAsの各層の膜厚がDBR全体にわたり不 均一であり $\mathrm{AlAs} / \mathrm{GaAs}$ 界面で平坦性が損なわ 
れている。また, 原子間力顕微鏡(AFM; atomic force microscope)を使用した表面観察の結 果では約 $80 \mathrm{~nm}$ の凹があることが明らかに なった ${ }^{12)}$ 。これは, GaAsがSi基板上に成長す る初期段階で, 3次元Volmer-Weber型, ある いはStranski-Krastanow型により3次元成長す ることに起因しているものと思われる。これら はAlAs/GaAs DBRの反射率低下につながって いる。一方, $\mathrm{AuZn} / \mathrm{Au}$ 金属反射鏡は, $600 \mathrm{~nm}$ $950 \mathrm{~nm}$ の広波長带域で $95 \%$ 以上の反射率が得 られた。

室温パルス駆動時(パルス幅 $0.1 \mu \mathrm{s}$, 周期 $1 \mu \mathrm{s})$ の電流-光出力特性を Fig. 4に示す。閾值電 流は79 mA(閾值電流密度 $4.9 \mathrm{kA} / \mathrm{cm}^{2}$ ) であり, 発振波長は $840 \mathrm{~nm}$, その半值幅は $0.28 \mathrm{~nm}$ で あった。

\section{$2.4 \mathrm{Si}$ 基板上 $\mathrm{AlGaAs} / \mathrm{GaAs}$ 面発光レーザー の結晶性改善}

$\mathrm{Si}$ 基板上面発光レーザーの室温連続発振に向 けて, 反射鏡の反射率向上と同時に結晶性改善 が重要である。そこで, $\mathrm{AlGaAs} / \mathrm{GaAs}$ 面発光 レーザー構造の成長層をポスト(円柱)型にSi 基板までエッチングし，さらにアニール処理 を施すことにより，成長層の残留応力の緩和 と結晶性改善を試みた。Fig. 5 に Si 基板上 $\mathrm{AlGaAs} / \mathrm{GaAs}$ 面発光レーザーを $30 \mu \mathrm{m} \phi$ のポス ト型にエッチングした表面SEM写真と, $850{ }^{\circ} \mathrm{C}$ で1時間アニール $\left(\mathrm{AsH}_{3}\right.$ 䨌囲気中 $)$ を施す前後で の低温(133 K)カソードルミネッセンス $(\mathrm{CL}$; cathodoluminescence)像を示す。ただし，CL 像は各CL強度が最大となる波長で観察したも のである。また, Fig. 6に各々のCL分光特性を 示す。ポスト型に加工しない場合にはCL強度 最大波長は $824 \mathrm{~nm}$ であったが, $30 \mu \mathrm{m} \phi$ のポス ト型にすると $814 \mathrm{~nm}$ に短波長シフトした。 $\mathrm{GaAs}$ 基板上に作製した同構造の面発光レー ザーでは，CL強度は811 nmで最大になること を考慮すると， $30 \mu \mathrm{m} \phi に \mathrm{GaAs}$ 成長層を低減 することにより(引っ張り)残留応力が大幅に緩 和されていることが推測される。次に, $30 \mu \mathrm{m} \phi$
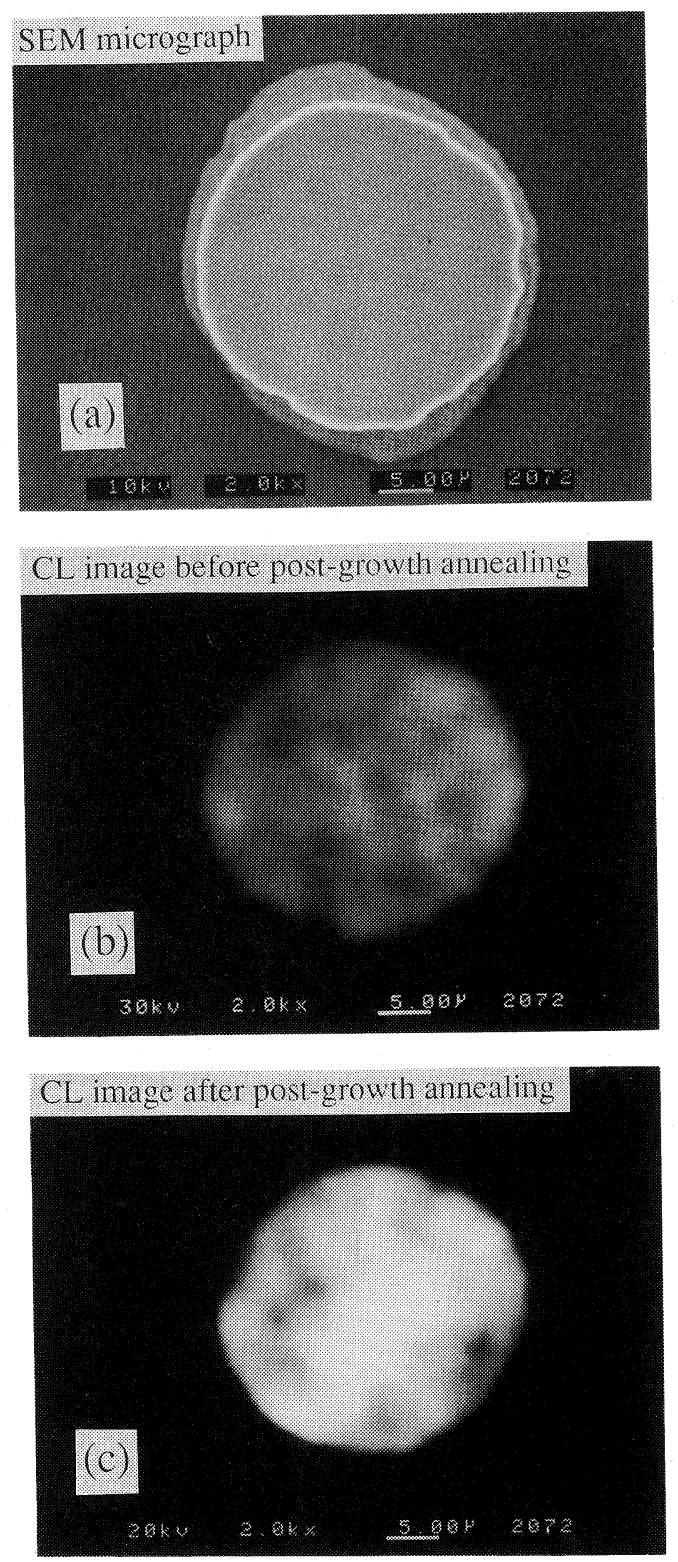

Fig. 5 (a) Top-viewed SEM micrograph of a $30 \mu \mathrm{m} \phi$ post-growth patterned VCSEL on Si and (b), (c) CL images at the each peak wavelength of the VCSELs on Si before and after post-growth annealing, respectively.

の面発光レーザーにアニールを施すことによ り, CL強度は約10倍増加し活性層の結晶性が 大幅に改善されている様子がわかる。ここで, アニール後のレーザーのCL強度最大波長は 


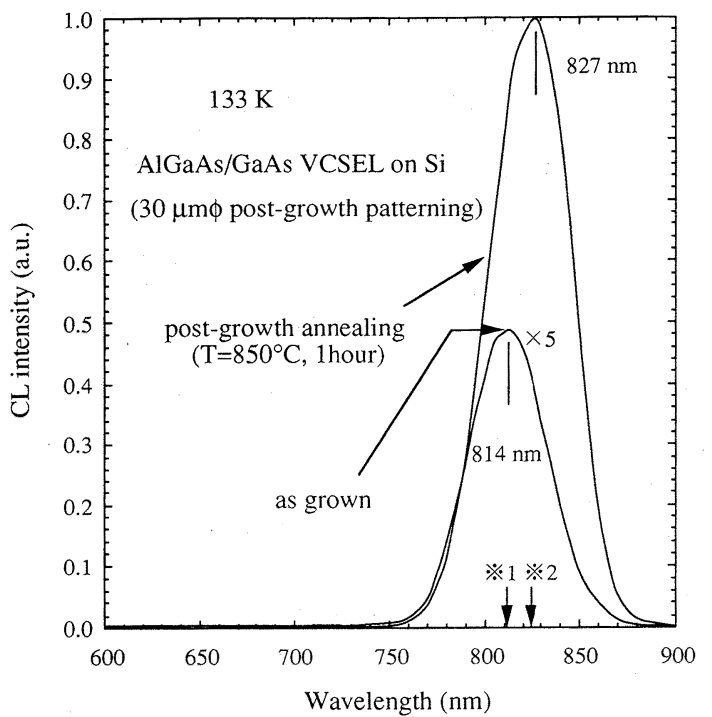

Fig. 6 CL spectra of VCSELs on Si in Fig. 5 (b) and (c) at $133 \mathrm{~K}$, recorded at $30 \mathrm{kV}$ beam voltage. $※ 1$ : peak wavelength of an AlGaAs/GaAs VCSEL on GaAs $(811 \mathrm{~nm})$. ※ : peak wavelength of an $\mathrm{AlGaAs} / \mathrm{GaAs}$ VCSEL on Si without post-growth patterning and annealing $(824 \mathrm{~nm})$.

$827 \mathrm{~nm}$ であるが，これは(Si基板上GaAs層の) 結晶性改善により引っ張り応力が増加したため であると思われる。これでは応力の緩和と結晶 性改善を同時に満足できていない。そこで，口 径を $7 \mu \mathrm{m} \phi$ とさらに微小化しアニールを施す ことにより，CL像では暗部(転位などの欠陥に よる非発光部分)がほとんど観察されず，また CL強度も $818 \mathrm{~nm}$ で最大となり, 結晶性と応力 の両方が改善されていることが確認された。

\section{Si基板上擬量子細線レーザー}

\section{1 $\mathrm{Si}$ 基板上 $\mathrm{AlGaAs} / \mathrm{GaAs}$ 擬量子細線レー} ザーの作製

$\mathrm{Si}$ 基板上 $\mathrm{GaAs}$ 系レーザーの活性層を従来の 量子井戸から量子細線化することで，その体積 を低減し，活性層に含まれる転位数を大幅に減 少させることができる。さらに，体積効果によ りレーザーの駆動電流も低減できるため, 転位 の成長抑制に有利であり寿命改善が期待され
$ろ^{8)}$ 。Fig. 7に $\mathrm{Si}$ 基板上 $\mathrm{AlGaAs} / \mathrm{GaAs}$ 擬量子細 線レーザーの作製プロセスを示す。以下，結晶 成長条件は上記 2.1 項と同様である。まず, $\mathrm{n}^{+}-\mathrm{Si}$ 基板上に $\mathrm{n}^{+}, \mathrm{p}^{+}-\mathrm{GaAs}$ バッファー層(1.6 $\mu \mathrm{m}, 1.0 \mu \mathrm{m})$ を二段階成長法で成長し熱サイク ルアニールを施す(Fig. 7-a)。次に, 幅 $2.7 \mu \mathrm{m}$, 深さ1.2 $\mu \mathrm{m}$ のV溝を[011]方向にエッチングによ り形成する(Fig. 7-b)。この結果, $\mathrm{p}^{+}$-GaAs層 は電流ブロック層の役割を果たし，V溝中央部
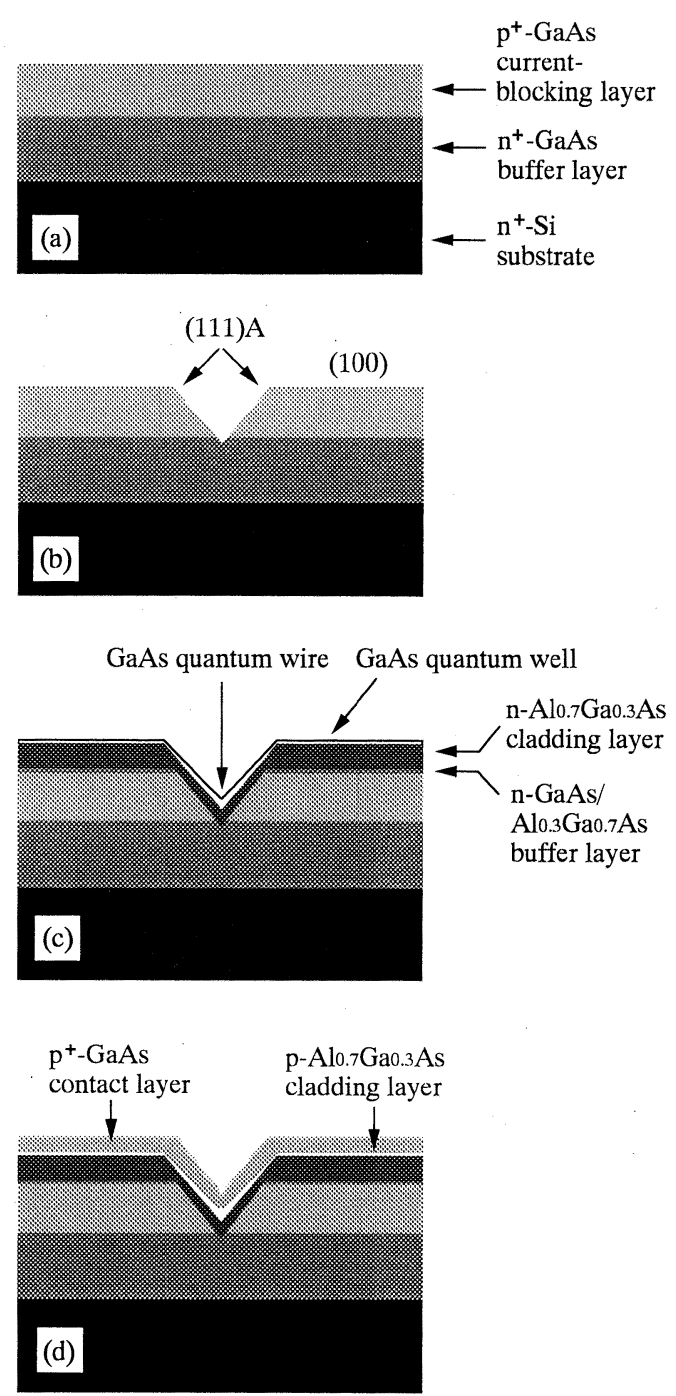

Fig. 7 Schematic fabrication sequence of an $\mathrm{AlGaAs} / \mathrm{GaAs}$ quantum wire-like laser on Si. 

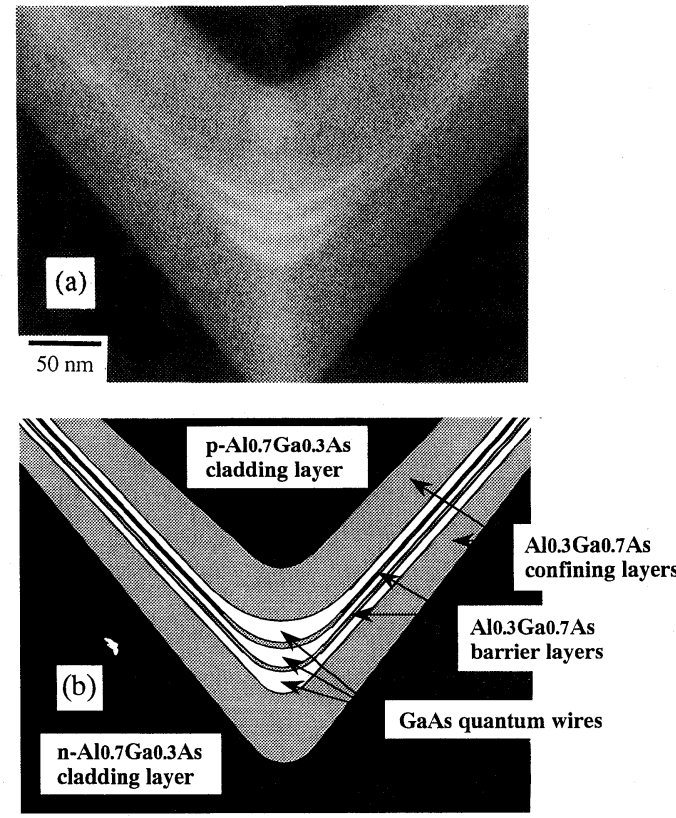

Fig. 8 Cross-sectional image of vertically-stacked GaAs quasi-quantum wires near the center of the V-groove in Fig. 7: (a) SEM micrograph and (b) schematic diagram.

の GaAs量子細線部に電流が有効に注入される ようになる。その後, 5ペアのn-GaAs(10 nm)/ $\mathrm{n}-\mathrm{Al}_{0.3} \mathrm{Ga}_{0.7} \mathrm{As}(10 \mathrm{~nm})$ 超格子バッファー層, $\mathrm{p}$, $\mathrm{n}-\mathrm{Al}_{0.7} \mathrm{Ga}_{0.3} \mathrm{As}$ クラッド層 (各 $0.51 \mu \mathrm{m}$ ), $\mathrm{Al}_{0.3} \mathrm{Ga}_{0.7} \mathrm{As}$ バリア層(各5.5 nm)と $\mathrm{GaAs}$ 多重(3 層)量子井戸(各7 $\mathrm{nm}$ )を $\mathrm{Al}_{0.3} \mathrm{Ga}_{0.7} \mathrm{As}$ 層(上下各 $60 \mathrm{~nm})$ で挟んだ $\mathrm{SCH}$ 構造, $\mathrm{p}^{+}-\mathrm{GaAs}$ コンタ 卜層 $(80 \mathrm{~nm})$ で構成されるレーザー構造を再成 長する(Fig. 7-c, d)。本研究でのGaAs層の成長 速度は $(100)>(111) \mathrm{A}$ 関係にある。このため, $\mathrm{GaAs}$ 量子井戸を成長すると V 溝の側面は (111)Aであるために，V溝中央の(100)底部で $\mathrm{GaAs}$ の成長が進み量子細線が形成される(Fig. 7-c)。Fig. 8にGaAs擬多重量子細線の断面SEM 写真を示す。薄い $\mathrm{Al}_{0.3} \mathrm{Ga}_{0.7} \mathrm{As}$ バリア層を介し てGaAs量子細線が3層積層しているために， そのサイズにばらつきが生じており ${ }^{13)}$, 縦幅 $(11 \mathrm{~nm}-15 \mathrm{~nm}) \times$ 横幅 $(83 \mathrm{~nm}-127 \mathrm{~nm})$ の擬量子 細線が形成されている。このため,この擬量子
細線レーザーでは, 従来の量子井戸レーザー8)

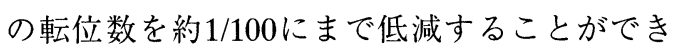
ることになる。

\section{2 $\mathrm{Si}$ 基板上 $\mathrm{AlGaAs} / \mathrm{GaAs}$ 擬量子細線レー ザーの諸特性}

量子細線部への電流狭窄は, V溝直上に幅 $2 \mu \mathrm{m} の \mathrm{SiO}_{2}$ 絶縁膜の電極空を設けることで 行っている。Fig. 9に室温パルス駆動時(パルス 幅 $0.2 \mu \mathrm{s}$, 周期 $200 \mu \mathrm{s}$ ) の電流-光出力特性(共振 器長 $123 \mu \mathrm{m}$ )を示す ${ }^{14-16)}$ 。閾值電流9.8 $\mathrm{mA}$, 外

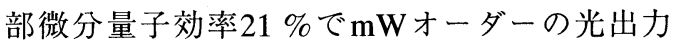
を得ている。発振波長は $859 \mathrm{~nm}$ であった。我々 は室温連続発振も得ており, 共振器長 $150 \mu \mathrm{m}$ $380 \mu \mathrm{m}$ の範囲において閾值電流は $16 \mathrm{~mA}-20$ $\mathrm{mA}$ であった。特に $9.8 \mathrm{~mA}$ の室温パルス及び 16 $\mathrm{mA}$ の室温連続発振は，これまで報告されてい る $\mathrm{Si}$ 基板上レーザー中で最小值を記録してい る。しかしながら，この量子細線は $\mathrm{GaAs} / \mathrm{Si}$ の 界面付近の転位数の多い位置に形成されている ため，低閾值発振は得ているが寿命改善には 至っていない。現在，さらに微小な量子細線 $(6 \mathrm{~nm} \times 17 \mathrm{~nm})$ を形成しており, 今後の長寿命

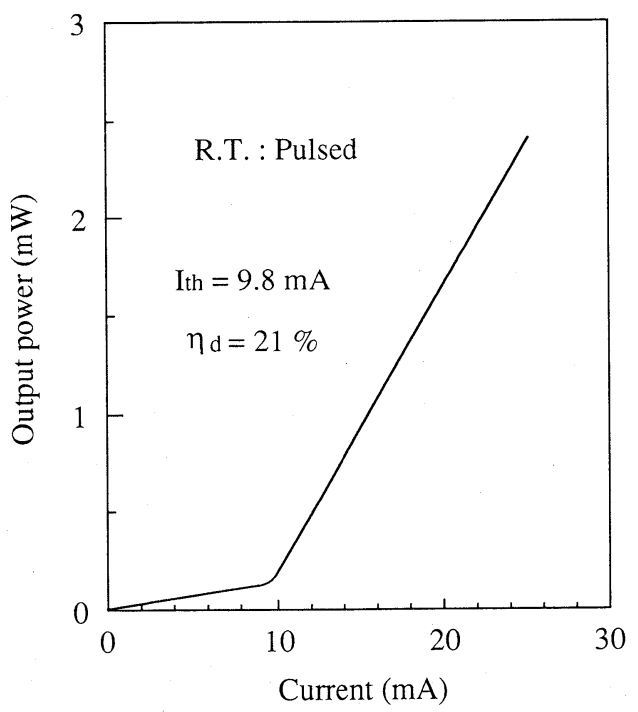

Fig. 9 Light versus current characteristic of a quantum wire-like laser on Si under pulsed condition at room temperature. 
化も含めた特性改善が期待される。

\section{Si基板上自己形成ドット状活性層発光ダ イオード}

4.1 Droplet epitaxy法によるGaAsドット状 結晶の自己形成

最近, Stranski-Krastanow 成長モード17), droplet epitaxy 法 $^{18)}$ 及び(311)B GaAs 基板上成 長 $^{19)}$ などにより，高品質GaAs及びInGaAsドッ トを GaAs基板上に直接成長する試みが注目さ

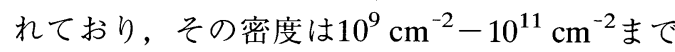
制御されている。この手法は上記 2.4 項のよう なエッチングによる加工を必要としないため, 加工ダメージを受けずにサイズを極微小化でき る。このため, $\mathrm{Si}$ 基板上にこのドットを形成す ることにより， $10^{6} \mathrm{~cm}^{-2}$ 台の転位密度の影響を 大幅に回避できるものと思われる。そこで, 我々 はdroplet epitaxy法を用いて $\mathrm{Si}$ 基板上に GaAs

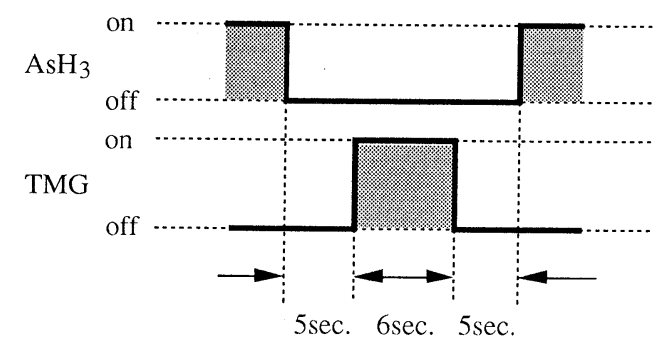

Fig. 10 Typical sequence of TMG and $\mathrm{AsH}_{3}$ supply for droplet epitaxy.

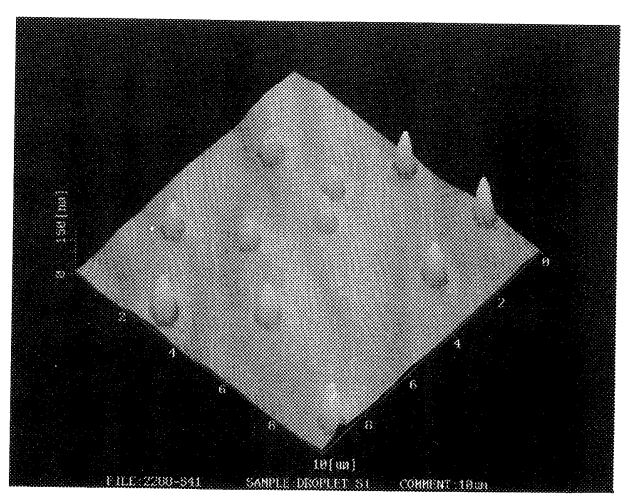

Fig. 11 AFM image of self-assembled GaAs dots on $\mathrm{GaAs} / \mathrm{Si}$.
ドット状結晶を自己形成し，さらに $\mathrm{Si}$ 基板上 LEDの活性層に応用することを試みた。Fig. 10 にdroplet epitaxy法の成長シーケンスを示 す。成長温度は $700{ }^{\circ} \mathrm{C}$ である。Fig. 10において, $\mathrm{AsH}_{3}$ 遮断後に $\mathrm{H}_{2}$ パージを行い, 続く $\mathrm{TMG}$ 供 給時にGa-dropletsが形成される。その後, $\mathrm{H}_{2}$ パージを経て再び $\mathrm{AsH}_{3}$ を供給する。この過程 で, VLS(vapor-liquid-solid) 成長機構により Ga-dropletsがドット状のGaAs微細結晶にな る。Fig. $11 に \mathrm{GaAs} / \mathrm{Si}$ 基板( $\mathrm{Si}$ 基板上に GaAs層 を2.5 $\mu \mathrm{m}$ 成長した基板)上に自己形成した $\mathrm{GaAs}$ ドット状結晶の AFM像を示す。微小な円錐状 の GaAs 結晶が $1-2 \times 10^{7} \mathrm{~cm}^{-2}$ の密度でランダム に形成されている。

\section{2 $\mathrm{Si}$ 基板上 $\mathrm{GaAs}$ ドット状活性層}

\section{$\mathrm{AlGaAs} / \mathrm{GaAs}$ LEDの作製}

上記 4.1 項 の $\mathrm{n}^{+}-\mathrm{GaAs} / \mathrm{Si}$ 基板上に $\mathrm{n}$ $\mathrm{Al}_{0.7} \mathrm{Ga}_{0.3} \mathrm{As}$ クラッド層 $(0.74 \mu \mathrm{m})$, droplet epitaxy法で自己形成したGaAsドット状活性層 を $\mathrm{Al}_{0.3} \mathrm{Ga}_{0.7} \mathrm{As}$ 層 (上下各 $70 \mathrm{~nm}$ ) で挟んだ $\mathrm{SCH}$ 構造, 続いて $\mathrm{p}-\mathrm{Al}_{0.7} \mathrm{Ga}_{0.3} \mathrm{As}$ クラッド層 $(0.74$ $\mu \mathrm{m})$ 及び $\mathrm{p}^{+}-\mathrm{GaAs}$ コンタクト層 $(80 \mathrm{~nm})$ を成長 し，面発光型のLED構造を作製した。

\section{$4.3 \mathrm{Si}$ 基板上GaAsドット状活性層 AlGaAs/GaAs LEDの諸特性}

Fig. 12 に室温直流電流 (dc; direct current)駆

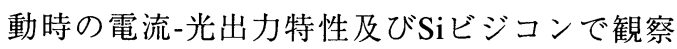
した表面エレクトロルミネッセンス(EL; electroluminescence) 像を示す。個々の GaAsドッ トが発光している様子が明暸に確認できる。光 出力は $10 \mu \mathrm{W}$ までは注入電流に比例して増加 し，以降は飽和傾向にある。また， $40 \mathrm{~mA}$ 電流 注入 $(3 \mu \mathrm{W}$ 出力) 時に中心波長は約 $866 \mathrm{~nm}$ で あった。

次に,このLEDの信頼性を確認するため, 室温一定電流(ACC; automatic current control) 寿命試験を注入電流 $60 \mathrm{~mA}$ (電流密度 $0.5 \mathrm{kA}$ / $\mathrm{cm}^{2}$ )の条件で行った。Fig. 13に初期值で規格 化した光出力の経時変化を示す。また, 従来 


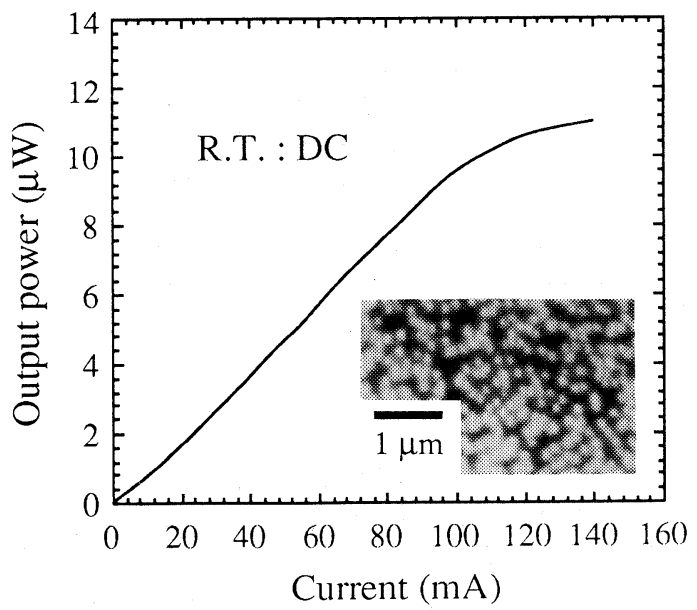

Fig. 12 Light versus current characteristic under dc condition at room temperature and topviewed EL topograph.

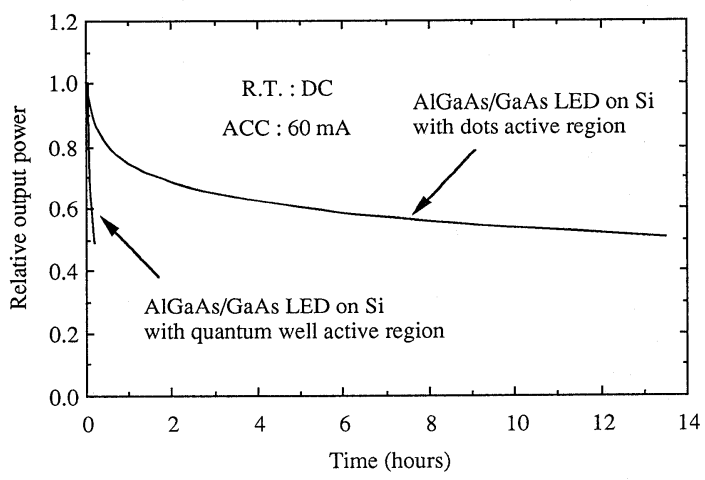

Fig. 13 Results of ACC aging tests for AlGaAs/ GaAs LEDs on Si with GaAs dots active region and a quantum well active region.

の $\mathrm{Si}$ 基板上 $\mathrm{AlGaAs} / \mathrm{GaAs}$ 量子井戸構造 $(\mathrm{GaAs}$ 量子井戸厚 $9 \mathrm{~nm})^{8)}$ でも同様のLEDを作製し比 較した。従来の量子井戸LEDでは通電後急速 に劣化し数分で光出力が半減した。これは, $\mathrm{Si}$ 基板上量子井戸レーザーの劣化 ${ }^{8)}$ と同様, $<100>$ 暗線欠陷(DLD; dark line defect)の成長 に起因していることがEL観察により確認され た。一方, GaAsドット状活性層を有するLED では劣化の進行が大幅に抑制され(EL観察によ りDLDの成長が抑制されていることを確認), 光出力半減には約14時間を要した。したがって, $\mathrm{Si}$ 基板上 GaAs系発光デバイスの活性領域が従
来の量子井戸構造のような薄膜の場合には，< $100>\mathrm{DLD}$ が転位成長面((110)面)上にのって容 易に増殖し急速劣化を伴う。しかしながら，ドッ 卜状の三次元微細構造の場合には, その密度が 転位密度に近く転位を含まない領域が存在する ことと，ドット状であるために転位成長面が断 絶されDLDの成長が抑制されたことにより寿 命改善に至ったものと思われる。

\section{5. おわりに}

ヘテロエピタキシャル成長技術を用いたSi基 板上半導体レーザーの寿命改善及び高性能化へ の我々のアプローチを中心に述べた。実用化に 向けた信頼性のある $\mathrm{Si}$ 基板上 $\mathrm{GaAs}$ 系レーザー の実現には，転位密度を $10^{4} \mathrm{~cm}^{-2}$ 台にまで低減 することが必要であると考えられているが，現 状では $10^{6} \mathrm{~cm}^{-2}$ 台に留まっている。我々は活性 領域を大幅に低減することで寿命改善を図る具 体的なデバイスを提案し作製している。今後, 物性定数差を超越したへテロエピタキシャル半 導体レーザーが実現されると，既存しない新概 念のデバイスが創出され多岐に及ぶ応用範囲が 考えられるため，この分野の発展が大いに期待 される。

\section{謝辞}

AFM観察及びLED作製に協力して頂いた本 学工学研究科庭野裕氏, 田中敦史氏に感謝致し ます。本研究の一部は文部省科学研究費 (No. 06555013)の援助を受けて行なった。また，著 者の一人(長谷川)は日本学術振興会から特別研 究員として援助を受けている。

\section{参 考 文 献}

1) N. Nakayama, S. Itoh, T. Ohata, K. Nakano, H. Okuyama, M. Ozawa, A. Ishibashi, M. Ikeda and Y. Mori: Electron. Lett. 29 (1993) 1488.

2) J. M. DePuydt, M. A. Haase, S. Guha, J. Qiu, H. Cheng, B. J. Wu, G. E. Hofler, G. MeisHaugen, M. S. Hagedorn and P. F. Baude: J. Cryst. Growth 138 (1994) 667.

3) S. Nakamura, T. Mukai and M. Senoh: Appl. 
Phys. Lett. 64 (1994) 1687.

4) S. D. Lester, F. A. Ponce, M. G. Craford and D. A. Steigerwald: Appl. Phys. Lett. 66 (1995) 1249.

5) H. P. Lee, X. Liu and S. Wang: Appl. Phys. Lett. 56 (1990) 1014.

6) D. C. Hall, N. Holonyak, Jr., D. G. Deppe, M. J. Ries, R. J. Matyi, H. Shichijo and J. E. Epler: J. Appl. Phys. 69 (1991) 6844.

7) T. Egawa, Y. Hasegawa, T. Jimbo and $M$. Umeno: Jpn. J. Appl. Phys. 31 (1992) 791.

8) 長谷川義晃, 江川孝志, 神保孝志, 梅野正義 : レーザー研究 22 (1994) 977.

9) Y. H. Lo, R. Bhat, D. M. Hwang, C. Chua and C.-H. Lin: Appl. Phys. Lett. 62 (1993) 1038.

10) E. A. Fitzgerald: J. Vac. Sci. Technol. B7 (1989) 782.

11) T. Egawa, T. Deguchi, Y. Hasegawa, T. Jimbo and M. Umeno: Extended Abstracts of the 1993 Int. Conf. on Solid State Devices and Materials, Chiba (1993) p. 1032.

12) T. Egawa, Y. Hasegawa, T. Jimbo and M.
Umeno: IEEE Photon. Technol. Lett. 6 (1994) 681.

13) E. Kapon, M. Walther, J. Christen, M. Grundmann, C. Caneau, D. M. Hwang, E. Colas, R. Bhat, G. H. Song and D. Bimberg: Superlattices and microstructures 12 (1992) 491.

14) Y. Hasegawa, T. Egawa, T. Jimbo and M. Umeno: Jpn. J. Appl. Phys. 32 (1993) L997.

15) Y. Hasegawa, T. Egawa, T. Jimbo and M. Umeno: J. Cryst. Growth 145 (1994) 728.

16) Y. Hasegawa, T. Egawa, T. Jimbo and M. Umeno: Conference Digest of 14th IEEE International Semiconductor Laser Conference, Maui (1994) p. 75.

17) D. Leonard, M. Krishnamurthy, C. M. Reaves, S. P. Denbaars and P. M. Petroff: Appl. Phys. Lett. 63 (1993) 3203.

18) T. Ueda, Q. Z. Gao, E. Yamaichi, C. Yamagishi and M. Akiyama: J. Cryst. Growth 145 (1994) 707.

19) R. Nötzel, T. Fukui, H. Hasegawa, J. Temmyo and T. Tamamura: Appl. Phys. Lett. 65 (1994) 2854.

\section{レーザーワード}

\section{ヘテロエピタキシャル成長 (heteroepitaxial growth)}

ヘテロエピタキシャル成長とは， $\mathrm{GaAs}$ 基板上の $\mathrm{ZnSe}, \mathrm{Al}_{2} \mathrm{O}_{3}$ 基板上の $\mathrm{GaN}, \mathrm{Si}$ 基板上の GaAs, GaAs基板上のInP成長のような場合で, 結晶構造と格子定数のいずれも異なる場合や, 結晶構造は同じでも格子定数が大きく異なるような場合である。また，このような典型的な場 合の他に, $\mathrm{GaAs}$ 基板上の $\mathrm{Al}_{\mathrm{x}} \mathrm{Ga}_{1-\mathrm{x}} \mathrm{As}$, InP基板上の $\mathrm{In}_{0.53} \mathrm{Ga}_{0.47} \mathrm{As}$ 成長のように, 結晶構造は 同じで格子定数がわずかに異なったり，格子定数は一致していても両者の物質が異なる場合も ある。これらも広義でへテロエピタキシャル成長に分類することができる。 (長谷川義晃)

\section{格子制御 (lattice control)}

ヘテロエピタキシャル成長において, 両者に格子定数差があり臨界膜厚以上成長した場合, そのへテロ接合界面にミスフィット転位が発生するようになる。転位の存在は, 特に発光デバ イスにおいて特性や信頼性に悪影響を及ぼすため極力除外されることが望ましい。このため, 格子定数差がない材料の組み合わせ $(3,4$ 元混晶)でへテロ接合を形成するか，格子定数差があ る場合には臨界膜厚以内で成長し格子を歪ませるか, 界面で組成を徐々に(グレーデッドに)変 化させ転位密度を減少させるなどの格子制御がなされている。

(長谷川義晃)

\section{光電子集積回路 (optoelectronic integrated circuit)}

光電子集積回路(OEIC: optoelectronic integrated circuit)とは, 光デバイス(半導体レーザー, 発光ダイオード, フォトダイオードなど) と電子回路素子を同一半導体基板上にモノリシック に集積化したものであり, 受発光デバイスと信号処理用の電子回路の整合性を増すことができ る。さらに, 両機能を融合させることにより従来のSi-LSIでは実現できなかった新機能を創出 し，光配線や光コンピュータなどへの実現に貢献することが期待される。

(長谷川義晃) 